RESEARCH ARTICLE

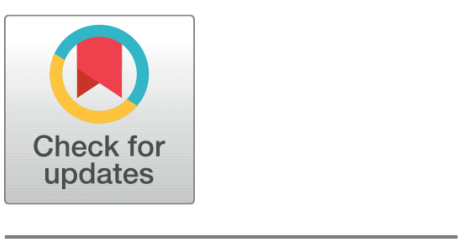

open ACCESS

Received: 29.05.2021

Accepted: 15.07 .2021

Published: 30.07 .2021

Citation: Ingle GS (2021) Strength and Swelling Behavior of Black Cotton Soil Stabilized with Waste Rubber Tyre. Indian Journal of Science and Technology 14(26): 2206-2214. https://doi.org/ 10.17485/IJST/v14i26.792

* Corresponding author.

ganesh.ingle@mitwpu.edu.in

Funding: None

Competing Interests: None

Copyright: @ 2021 Ingle. This is an open access article distributed under the terms of the Creative Commons Attribution License, which permits unrestricted use, distribution, and reproduction in any medium, provided the original author and source are credited.

Published By Indian Society for Education and Environment (iSee)

ISSN

Print: 0974-6846

Electronic: 0974-5645

\section{Strength and Swelling Behavior of Black Cotton Soil Stabilized with Waste Rubber Tyre}

\author{
Ganesh S Ingle ${ }^{1 *}$ \\ 1 Associate Professor, School of Civil Engineering, Dr. Vishwanath Karad MIT World Peace \\ University, Pune, 411038, India
}

\section{Abstract}

Objectives: To determine the strength and swelling behavior of black cotton soil (expansive soil) using a shredded rubber tyre as an additive. Methods: Series of unconfined compressive strength and California Bearing Ratio (CBR) tests were carried out on black cotton soil mixed with $0 \%, 5 \%, 10 \%$, and $15 \%$ of shredded rubber tyres, and the results were compared with untreated soil samples. The study also investigated the influence of shredded rubber on swelling characteristics of black cotton soil by performing the swelling pressure test. Findings: From the experimental results, it is inferred that the optimum addition of a $10 \%$ shredded rubber tyre can effectively improve the strength behavior of black cotton soil. The unconfined compressive strength and California Bearing Ratio (CBR) of soil stabilized with $10 \%$ of shredded rubber tyre increased by $32 \%$ and $49.3 \%$ respectively as compared to the untreated soil. An illustration presented shows the effect of increased CBR in terms of the reduction of $18 \%$ pavement thickness. This may reduce the total cost of the project. The present study also investigated the swelling potential of Black cotton soil and it is found to be decreased by $33.33 \%$ for the addition of $15 \%$ shredded rubber soil as compared to untreated soil. Novelty: The use of shredded rubber in expansive soil increased its CBR value, leading to a reduction in $18 \%$ of pavement thickness. Hence, it may lead to a further reduction in the total cost of the project. Also, the disposal problem of waste rubber tyres is resolved up to a certain extent.

Keywords: Shredded Rubber Tyre; Black Cotton Soil; Unconfined Compressive Strength; California Bearing Ratio; Soil Stabilization

\section{Introduction}

In India, almost $20 \%$ of the land is covered by Black cotton soil (expansive soil). The special characteristics of this soil is its swelling and shrinkage behavior. Large volume changes are observed due to change in the moisture content of soil ${ }^{(1,2)}$. These moisture variations develop deformations in soil and are responsible for damage or destruction to the civil engineering structures ${ }^{(3)}$. The swelling and shrinkage characteristics of expansive soil can be minimized by using various techniques viz. prewetting the soil, 
complete or partial replacement of expansive soil, location of foundation below the depth of minimum volume change and soil stabilization by mechanical and chemical means ${ }^{(4)}$. Chemical soil stabilization is one of the most economical techniques which improves the engineering properties of expansive soils ${ }^{(5)}$. In chemical soil stabilization, numerous materials are used as an additive (traditional and non-traditional) such as cement, lime, bitumen, silica fume, furnace slag, stone dust, fly ash, bottom ash, pond ash, rice husk ash, fibers etc. ${ }^{(6-8)}$. Researchers studied the capability of these additives in expansive soil and observed the improvement in the engineering properties of expansive soil. However, these additives are having some problems associated with sulfate attack, environmental pollution due to the cement manufacture process, which is questionable considering the sustainability of using these traditional additives ${ }^{(9,10)}$. Also, few researchers reported that the addition of cement or lime increases the stiffness and brittleness of the expansive soil ${ }^{(11-14)}$. While this issue can be resolved by reinforcing the expansive soil by using natural or synthetic fibers such as polyester, polypropylene, glass, steel fiber ${ }^{(9,15,16)}$ this technique is costly and also requires trained personnel for its application ${ }^{(14)}$. One of the cost-effective and sustainable solutions for the above problems is the use of the shredded/crumb waste rubber tyre for the stabilization of expansive soil.

In India, a large number of automobile industries have been noticed and every year about 112 million waste rubber tyres are generated ${ }^{(17)}$. One of the biggest challenges is their safe disposal and management ${ }^{(14)}$. The common practice for disposal of waste tyres is stockpiling, landfilling, and incineration ${ }^{(14)}$, these practices cause a threat to the environment and various hazards to human health. Recycle and reuse of these waste rubber tyres can minimize the above issues. Researchers have studied the use of waste rubber tyres in concrete and asphalt pavement as partial replacement of fine or coarse aggregates ${ }^{(18,19)}$. However, in geotechnical engineering field, the research is limited especially in cohesive (clayey) soil ${ }^{(20)}$. Few researchers ${ }^{(21-24)}$ studied the compaction characteristics of the clayey soil with addition of waste rubber tyres and found it to decrease with the increment of rubber content, whereas few researchers ${ }^{(25-27)}$ reported no change in optimum moisture content with the inclusion of rubber content in clayey soil. On the other hand, few studies ${ }^{(28,29)}$ observed the increment in the optimum moisture content of clayey soil with addition of rubber content. The effect of rubber tyre on strength behavior of clayey is also studied by various investigators in terms of unconfined compression strength and or California Bearing Ratio (CBR). Many researchers ${ }^{(20,22,30,31)}$ observed increment in unconfined compressive strength of clayey soil while few investigators ${ }^{(23,32,33)}$ reported a reduction in unconfined compressive strength of clay with addition of rubber particles. Few studies ${ }^{(24,34)}$ reported that the inclusion of waste rubber up to $5 \%$ increases the CBR of clayey soil. Contrary to this, few researchers ${ }^{(33,35)}$ found the reduction in CBR of clayey soil with inclusion of rubber particles. Based on the above literature, it is clearly observed that further investigation is still required regarding the inclusion of waste rubber tyres on the strength behavior of clayey soil. Hence, the present study aims to examine the effect of shredded rubber tyres on the strength as well as swelling behavior of locally available black cotton soils.

\section{Materials and Methods}

\subsection{Black cotton soil}

Black Cotton soil is collected from the vicinity of Bhugaon, Pune (India). The properties (physical and engineering) of the collected soil are obtained in a geotechnical engineering laboratory and the results are tabulated in Table 1.

Table 1. Physical and Engineering properties of Black Cotton Soil

\begin{tabular}{lll}
\hline Sr. No & Properties & Value \\
\hline 1 & Colour & Black \\
& Atterberg limits: & \\
& a. Liquid limit (\%) & 56.8 \\
2 & b. Plastic limit (\%) & 41.9 \\
& c. Shrinkage limit (\%) & 16.83 \\
3 & Specific gravity & 2.51 \\
4 & IS Soil classification & MH \\
5 & Maximum dry unit weight $\left(\mathrm{kN} / \mathrm{m}^{3}\right)$ & 16.97 \\
6 & Optimum moisture content $(\%)$ & 24.30 \\
7 & Grain size distribution: a. Gravel and Sand $(\%)$ & 23.1 \\
& b. Silt and Clay (\%) & 76.9 \\
9 & Unconfined Compressive Strength $\left(\mathrm{kN} / \mathrm{m}^{2}\right)$ & 149 \\
\hline
\end{tabular}

https://www.indjst.org/ 


\subsection{Waste rubber tyre}

The waste rubber tyre was collected from the local dumping area and it was shredded into small pieces ranging from $2 \mathrm{~mm}$ to $10 \mathrm{~mm}$ in length. The shredded rubber was sorted from steel or nylon wires as shown in Figure 1. The physical properties of the shredded rubber tyres are presented in Table 2.

Table 2. Physical properties of shredded rubber tyre

\begin{tabular}{lll}
\hline Sr.no & Properties & Value \\
\hline 1 & Type & Shredded rubber \\
& Dimensions: & \\
2 & a. Length & 2 to $10 \mathrm{~mm}$ \\
& b.Thickness & 1 to $3 \mathrm{~mm}$ \\
3 & Specific gravity & 1.12 \\
4 & Colour & Black \\
\hline
\end{tabular}

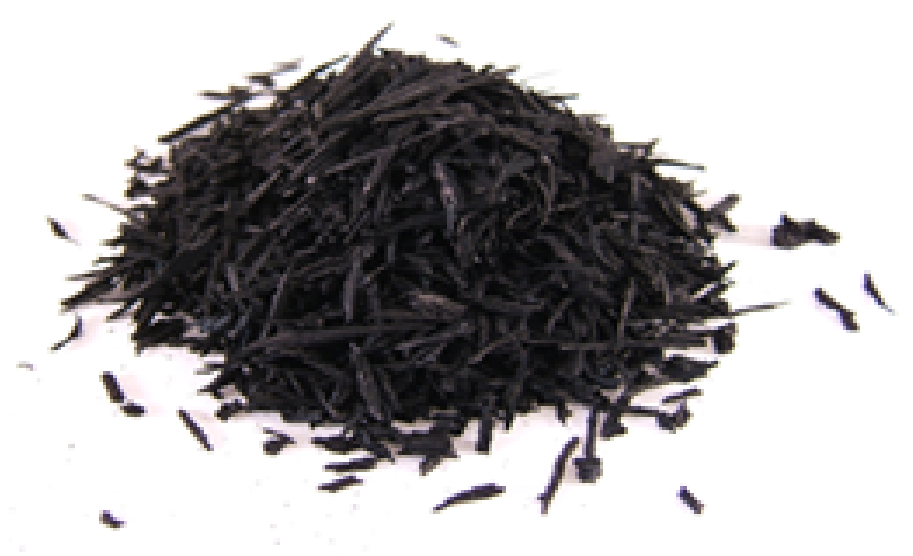

Fig 1. Shredded rubber tyre

\subsection{Mixing proportions}

The proportions of black cotton soil and shredded rubber tyres are decided and mixed systematically to obtain a uniform and compatible mixture. Table 3 shows the sample designation with soil and shredded rubber tyre proportion.

Table 3. Sample designation and \% of shredded rubber tyre

\begin{tabular}{lll}
\hline Sample designation & Soil (\%) & Shredded rubber tyre (\%) \\
\hline $0 \%$ SR & 100 & 0 \\
$5 \%$ SR & 95 & 5 \\
$10 \%$ SR & 90 & 10 \\
$15 \%$ SR & 85 & 15 \\
\hline
\end{tabular}

In the present study, the shredded rubber tyre is selected as an additive and randomly mixed with the soil for $0 \%, 5 \%, 10 \%$, and $15 \%$ by weight of soil. The $\%$ of rubber content is decided on the basis of previous studies ${ }^{(22,25,27,31,33,34,36)}$. The strength characteristics and swelling potential of treated soil are examined by performing the Unconfined compression strength test, CBR test, and Swelling pressure test respectively. 


\section{Result and Discussions}

\subsection{Compaction characteristics}

The maximum dry unit weight and optimum moisture content for the untreated and shredded rubber soil were obtained by performing the Standard Proctor test as per IS: 2720 (Part-VII) ${ }^{(37)}$. The compaction test result of untreated and shredded rubber soil $(5 \%, 10 \%$, and $15 \%)$ is shown in Figure 2. It is found that the maximum dry unit weight and optimum moisture content of soil decreases as the percentage of shredded rubber increases. The addition of $0 \%, 5 \%, 10 \%$ and $15 \%$ of rubber content decreases the maximum dry unit weight of expansive soil from $16.97 \mathrm{kN} / \mathrm{m}^{3}$ to $15.59 \mathrm{kN} / \mathrm{m}^{3}, 15.30 \mathrm{kN} / \mathrm{m}^{3}$ and $14.71 \mathrm{kN} / \mathrm{m}^{3}$ respectively. This may be because of the lightweight nature of rubber (specific gravity of 1.12) as compared with the soil grains (specific gravity $=2.51$ ), which turns into a lesser maximum dry unit weight. Also, the rubber shows the elastic (rebound) response during compaction which ultimately reduces the compaction effort/energy and hence the decrease in dry unit weight ${ }^{(14)}$. Similarly, the optimum moisture content decreases for shredded rubber soil. This is because of the less water retention capabilities of rubber as compared to soil. These results are found to be comparable with the previous studies ${ }^{(14-20)}$. The compaction testresult shows that the inclusion of rubber in expansive soil can be used as a light weight backfill material in case of retaining wall ${ }^{(24)}$.

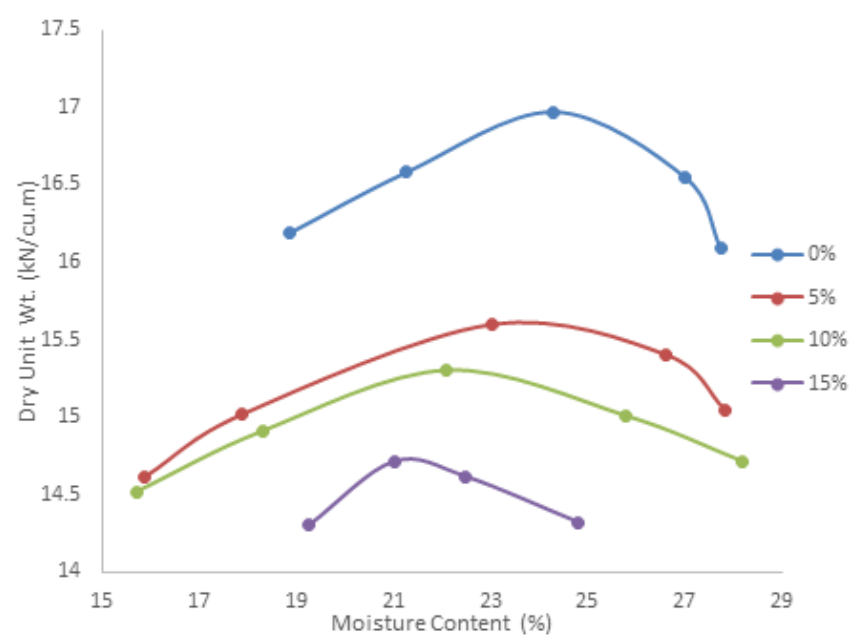

Fig 2. Dry unit weight and moisture content variation for untreated and shredded rubber soil

\subsection{Strength characteristics}

The strength characteristics of untreated and shredded rubber soil are obtained by performing the Unconfined compression strength test and California bearing test as per IS: 2720 (Part-X and Part- XVI) $)^{(38,39)}$

\subsubsection{Unconfined compression strength (UCS)}

The untreated and shredded rubber $(5 \%, 10 \%$, and $15 \%)$ soil samples were prepared at maximum dry density and optimum moisture content which was obtained corresponding to the soil/soil shredded rubber mixture. The axial stress-strain variation of untreated and shredded rubber soil is shown in Figure 3.

It is found that the peak axial stress of shredded rubber soil is increased with an increase in rubber content (5\% to $10 \%$ ), while it is decreased for $15 \%$ addition of shredded rubber. This may be attributed to the development of reinforcement mechanism due to interlocking and frictional resistance forces between the shredded rubber and soil particles ${ }^{(40)}$. The reinforcement effect may reduce the compression and heave of soil matrix and hence produce higher resistance to penetration. While for higher shredded rubber content (15\%) there may be a possibility of an increase in the rubber-to-rubber particle interaction leading to a decrease in the stress value. The failure strain of expansive soil is increased from $0.33 \%$ to $0.48 \%$ with the addition of $15 \%$ shredded rubber. This indicates that the inclusion of rubber in soil shows strain hardening behavior after achieving of the peak axial stress and decreases the rate of post- peak strength loss. This eventually increases the ductility of expansive soil ${ }^{(41)}$. Figure 4 shows the variation of UCS with the addition of a shredded rubber tyre. 


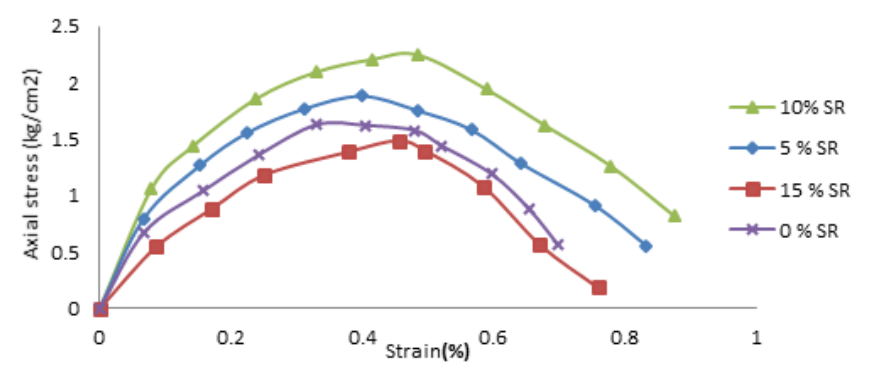

Fig 3. Stress- strain variation for untreated and shredded rubber soil

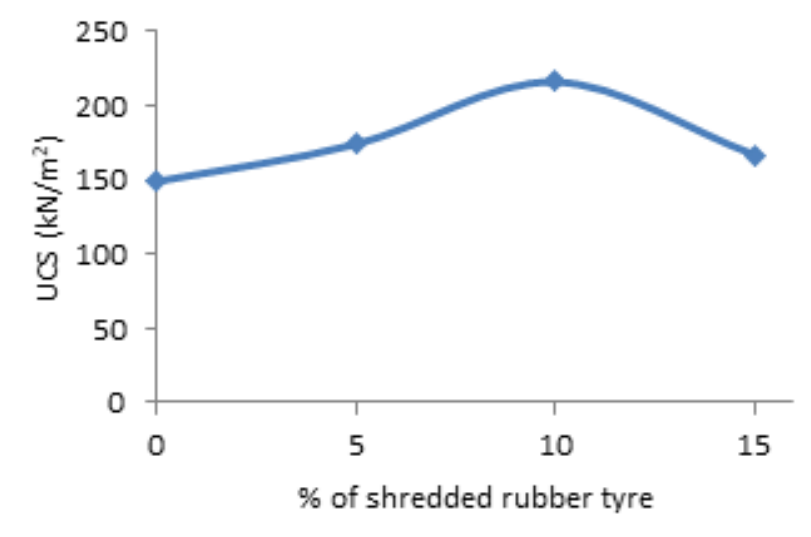

Fig 4. Variation of UCS with \% of shredded rubber

It may therefore be inferred that the UCS value increases up to $10 \%$ addition of shredded rubber, beyond which the addition of a higher percentage of shredded rubber creates the soil + rubber mixture in more compressible nature, which is further responsible for resisting the lesser load and lesser UCS value.

\subsubsection{California Bearing Ratio (CBR) test}

Unsoaked CBR test was conducted as per IS: 2720 (Part XVI) ${ }^{(39)}$ on untreated and shredded rubber (5\%,10\%, and15\%) soil samples. These samples were prepared at maximum dry density and optimum moisture content which was obtained corresponding to the soil/soil shredded rubber mixture. Figures 5 and 6 show the variation of load Vs penetration and CBR Vs shredded rubber content respectively.

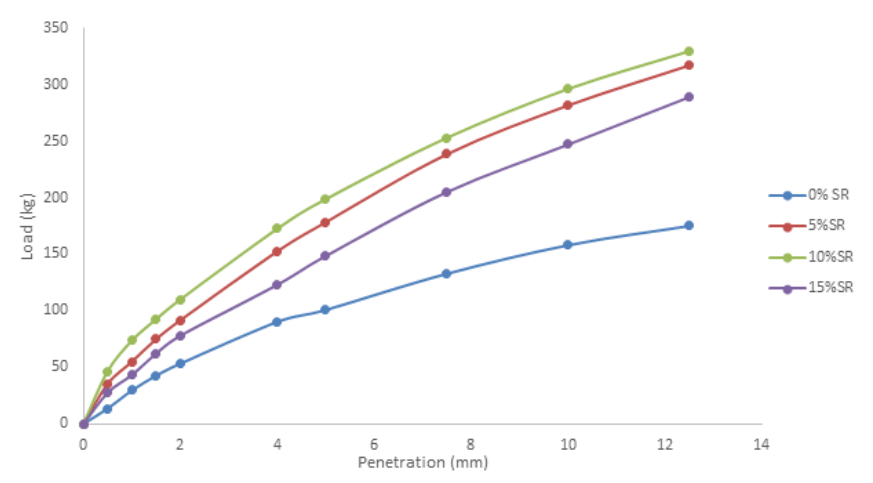

Fig 5. Load - penetration curve for the soil with varied $\%$ of shredded rubber 


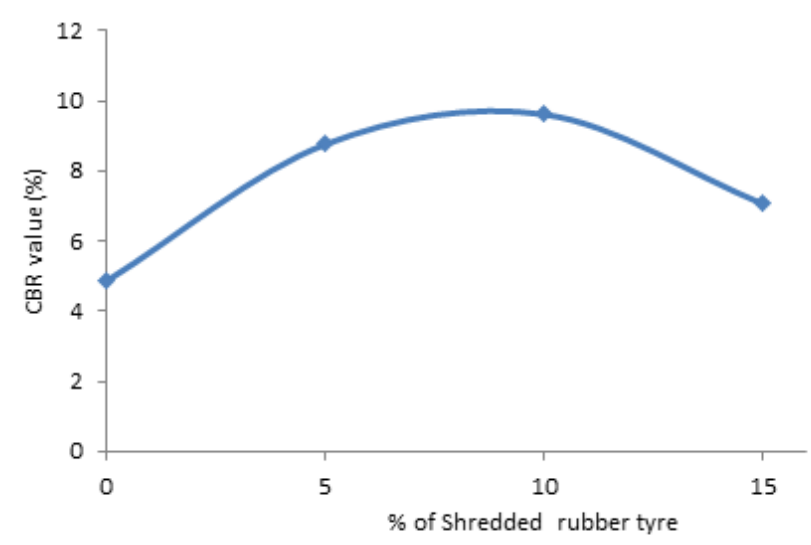

Fig 6. Variation of CBR value with different percentage of shredded rubber content in soil

Figure 5 clearly shows that the resistance to penetration of soil increases with an increase in the rubber content up to $10 \%$ and the CBR value of soil (Figure 6) increases from $4.87 \%$ to $9.61 \%$ with the inclusion of $10 \%$ rubber content. This may be because of the increment in the frictional component of composite matrix, which leads to increasing the load carrying capacity of soil mixture and hence the CBR value ${ }^{(36)}$. The inclusion of rubber content beyond $10 \%$ resulted in a loss of CBR value (decreased up to $7.01 \%$ ). This may be due to the availability of more quantity of rubber which may cause compressibility into the soil matrix. As rubber is more compressible than soil, the more quantity of rubber in the soil matrix results in more deformation which ultimately lowers the resistance to penetration. These findings are in good agreement with the observation made by other researchers ${ }^{(24,34)}$ and also are consistent with the UCS result.

\subsubsection{Swelling characteristics}

The swelling characteristics of untreated and shredded rubber soil are obtained by performing the swelling pressure test as per IS: 2720 (Part-41) ${ }^{(42)}$ and the variation of swelling pressure with \% of shredded rubber content is as shown in Figure 7.

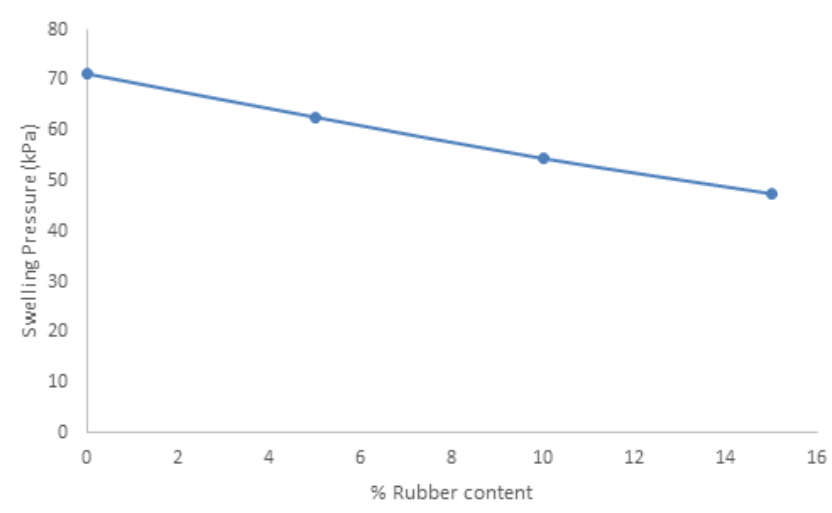

Fig 7. Variation of swelling pressure with $\%$ of shredded rubber content

It is observed that the swelling pressure of black cotton soil is decreased steadily as the \% of shredded rubber content is increased. The swelling pressure of untreated soil is $71.3 \mathrm{kPa}$, while it is decreased up to $47.5 \mathrm{kPa}$ for $15 \%$ addition of shredded rubber. This may be because of the replacement of swelling behavior soil particles by non-swelling rubber particles ${ }^{(43)}$. Also, the inclusion of non-polarized rubber content is responsible for the creation of drainage path and hence reduction in the pore pressure of the composite matrix, which ultimately reduces the swelling pressure ${ }^{(22)}$. 


\section{Illustrative Example}

In order to determine the impact of improvement of shredded rubber stabilized soil in the flexible pavement, data for a certain flexible pavement has been considered. The effectiveness of shredded rubber soil has been demonstrated through a reduction in flexible pavement thickness by using the Indian Road Congress (IRC)37-2001 ${ }^{(44)}$.

The design data is as follows;

1. CBR of untreated soil $=4.74 \%$

2. CBR of shredded rubber soil $=9.61 \%$

3. Design life $(\mathrm{n})=15$ years

4. Vehicle damage factor (V.D.F) $=2.5$

5. Traffic growth rate $(\mathrm{r})=7.5 \%$

6. Lane correction factor $(\mathrm{LCF})=0.75$

7. Traffic $(\mathrm{A})=400$ equivalent single axle load /day

As per IRC 37, the designed traffic in terms of the cumulative number of standard axles is obtained by the following equation

$$
\begin{gathered}
N=\frac{365 \times\left[(1+r)^{n}\right]-1}{r} \times A \times \text { V.D.F } \times L C F \\
N=\frac{365 x[(1+0.075) 15]-1}{0.075} \times 400 \times 2.5 \times 0.75 \\
N=7.2 \text { million standard axles }(\mathrm{msa}) \\
\text { Hence Design traffic is } 7.2 \mathrm{msa}
\end{gathered}
$$

For untreated soil, the CBR value is $4.74 \%$ and traffic is $7.2 \mathrm{msa}$ (from IRC 37-2001 page 24)

Total pavement thickness $=620 \mathrm{~mm}$

For subgrade soil stabilized with shredded rubber, the CBR value is $9.61 \%$ and traffic is $7.2 \mathrm{msa}$ (from IRC 37-2001 page 28) Total pavement thickness $=508 \mathrm{~mm}$

Hence, reduction in total pavement thickness is $=620-508=112 \mathrm{~mm}$

Thus, the reduction of pavement thickness is $18 \%$. Hence, it may lead to a further reduction in the total cost of the project.

\section{Conclusions}

From the experimental study, it is concluded that the maximum dry unit weight and optimum moisture content of expansive soil decreases as the $\%$ of shredded rubber content in the soil increases. This may be because of the lightweight nature of rubber and less water absorption capacity as compared with soil grains. The inclusion of shredded rubber content up to $10 \%$ improves the UCS value of expansive soil. Further addition of shredded rubber leads to a decrease in the UCS value. Unsoaked California bearing ratio increased from 4.87 to $9.61 \%$ with $10 \%$ addition of shredded rubber, for the further increment of rubber content the CBR value is decreased. For the addition of a $10 \%$ shredded rubber tyre, the strength behavior of black cotton soil viz. UCS and CBR increased by $32 \%$ and $49.3 \%$ respectively as compared to untreated soil. The swelling pressure of soil is decreased continuously as the rubber content is increased. For untreated soil, it is $71.3 \mathrm{kPa}$, while for $15 \%$ addition of shredded rubber it is $47.5 \mathrm{kPa}$.

From the illustration, it is observed that the increase in CBR value of shredded rubber soil reduced the total pavement thickness by $18 \%$ and hence the total cost of the project. This, therefore may also resolve the disposal problem of waste rubber tyre up to a certain extent.

Hence it is concluded that the shredded rubber up to $10 \%$ can be effectively used to improve the strength and swelling characteristics of Black cotton soil.

\section{Limitation and Future Scope}

In the present study, the shredded rubber tyre was mixed at the range of 5\% increment, while to obtain the exact optimum $\%$ of shredded rubber content this increment may be reduced up to $1 \%$ and further experimental investigations can be carried out. To better understand the interaction effect between the waste rubber tyre and expansive soil a microscopic analysis can be carried out by using Scanning Electron Microscopy (SEM) or any other method. 


\section{References}

1) Shukla R, Prasad N, Yadav P, Mankotia N. Problems and treatments of black cotton soil. Pune, India. 2015. Available from: https:/gndec.ac.in/ igs/ldh/ files/igc\%202015\%20pune/THEME\%202\%20CHALLENGES\%20IN\%20EXPANSIVE\%20SOILS/IGC-2015_submission_374.pdf.

2) Hubballi RM, Rahman SK, Paul A. Performance analysis of stone dust stabilized clayey soil from the Bilasipara region in North-Eastern India. International Journal of Advanced Research in Engineering and Technology. 2021;12(2):422-429. Available from: http://www.iaeme.com/IJARET/issues.asp?JType= IJARET\&VType $=12 \& I T y p e=2$.

3) Jalal FE, Xu Y, Jamhiri B, Memon SA. On the Recent Trends in Expansive Soil Stabilization Using Calcium-Based Stabilizer Materials (CSMs): A Comprehensive Review. Advances in Materials Science and Engineering. 2020;p. 1-23. Available from: https://dx.doi.org/10.1155/2020/1510969.

4) Obulreddy S, Kumar TK. A critical review on foundations in expansive soils. International Journal of Scientific Development and Research. 2019;4(2):13-18. Available from: https://www.ijsdr.org/papers/IJSDR1902004.pdf.

5) Liu J, Shi B, Jiang H, Huang H, Wang G, Kamai T. Research on the stabilization treatment of clay slope topsoil by organic polymer soil stabilizer. Engineering Geology. 2011;117(1-2):114-120. Available from: https://dx.doi.org/10.1016/j.enggeo.2010.10.011.

6) Ikeagwuani CC, Donald CN. Emerging trends in expansive soil stabilization: A review. Journal of Rock Mechanics and Geotechnical Engineering. 2017;11:423-440. Available from: https://doi.org/10.1016/j.jrmge.2018.08.013.

7) Mir BA, Samala HR. Mechanical behavior of Nano-material (Al2O3) stabilized soft soil. International Journal of Engineering. 2021;34(3):636-643. Available from: 10.5829/ije.2021.34.03c.07.

8) Yadav JS, Tiwari SK. Behavior of cement stabilized treated coir fibre- reinforced clay -pond ash mixtures. Journal of Building Engineering. 2016;8:131-140. Available from: https://doi.org/10.1016/j.jobe.2016.10.006.

9) Jayanti P, Singh DP. Utilization of sustainable materials for soil stabilization: State of the art. Journal of Advances in Civil Engineering Materials. 2016;5(1).

10) Firoozi AA, Olgun CG, Firoozi AA, Baghini MS. Fundamentals of soil stabilization. International Journal of Geo-Engineering. 2017;8(1):2-16. Available from: https://dx.doi.org/10.1186/s40703-017-0064-9.

11) Tang C, Shi B, Gao W, Chen F, Cai Y. Strength and mechanical behavior of short polypropylene fiber reinforced and cement stabilized clayey soil. Geotextiles and Geomembranes. 2007;25:194-202. Available from: https://dx.doi.org/10.1016/j.geotexmem.2006.11.002.

12) Fatahi B, Khabbaz H, Fatahi B. Mechanical characteristics of soft clay treated with fibre and cement. Geosynthetics International. 2012;19(3):252-262. Available from: https://dx.doi.org/10.1680/gein.12.00012.

13) Kumar A, Gupta D. Behavior of cement-stabilized fiber-reinforced pond ash, rice husk ash-soil mixtures. Geotextile and Geomembranes. $2016 ; 44: 466-474$. Available from: http://dx.doi.org/10.1016/j.geotexmem.2015.07.010.

14) Yadav JS, Tiwari SK. Effect of inclusion of crumb rubber on the unconfined compressive strength and wet-dry durability of cement stabilized clayey soil. Journal of Building Materials Structures. 2016;03:68-84. Available from: http://journals.lagh-univ.dz/index.php/jbms/article/view/25.

15) Kumar A, Walia BS, Bajaj A. Influence of Fly Ash, Lime, and Polyester Fibers on Compaction and Strength Properties of Expansive Soil. Journal of Materials in Civil Engineering. 2007;19(3):242-248. Available from: https://dx.doi.org/10.1061/(asce)0899-1561(2007)19:3(242).

16) Nguyen L, Fatahi B. Behaviour of clay treated with cement \& fibre while capturing cementation degradation and fibre failure - C3F Model. International Journal of Plasticity. 2016;81:168-195. Available from: https://dx.doi.org/10.1016/j.ijplas.2016.01.015.

17) Thomas BS, Gupta RC, Panicker VJ. Recycling of waste tire rubber as aggregate in concrete: durability-related performance. Journal of Cleaner Production. 2016;112:504-513. Available from: https://dx.doi.org/10.1016/j.jclepro.2015.08.046.

18) Angelin AF, Andrade MFF, Bonatti R, Lintz RCC, Gachet-Barbosa LA, Osório WR. Effects of spheroid and fiber-like waste-tire rubbers on interrelation of strength-to-porosity in rubberized cement and mortars. Construction and Building Materials. 2015;95:525-536. Available from: https://dx.doi.org/10. 1016/j.conbuildmat.2015.07.166.

19) Gupta T, Chaudhary S, Sharma RK. Mechanical and durability properties of waste rubber fiber concrete with and without silica fume. Journal of Cleaner Production. 2016;112:702-711. Available from: https://dx.doi.org/10.1016/j.jclepro.2015.07.081.

20) Yadav JS, Tiwari SK. Effect of waste rubber fibers on the geotechnical properties of clay stabilized with cement. Applied Clay Science. 2017;149:97-110. Available from: http://dx.doi.org/10.1016/j.clay.2017.07.037.

21) Cetin H, Fener M, Gunaydin O. Geotechnical properties of tire-cohesive clayey soil mixtures as a fill material. Engineering Geology. 2006;88(1-2):110-120. Available from: https://dx.doi.org/10.1016/j.enggeo.2006.09.002.

22) Kalkan E. Preparation of scrap tire rubber fiber-silica fume mixtures for modification of clayey soils. Applied Clay Science. 2013;80-81(81):117-125. Available from: https://dx.doi.org/10.1016/j.clay.2013.06.014.

23) Signes CH, Garzón-Roca J, Fernández PM, de la Torre MEG, Franco RI. Swelling potential reduction of Spanish argillaceous marlstone Facies Tap soil through the addition of crumb rubber particles from scrap tyres. Applied Clay Science. 2016;132-133(132):768-773. Available from: https: //dx.doi.org/10.1016/j.clay.2016.07.027.

24) Yadav JS, Tiwari SK. The impact of end-of-life tires on the mechanical properties of fine-grained soil: A Review. Environment, Development and Sustainability: A Multidisciplinary Approach to the Theory and Practice of Sustainable Development. 2017;2:485-568. Available from: 10.1007/s10668017-0054-2.

25) Al-Tabbaa A, Blackwell O, Porter SA. An Investigation into the Geotechnical Properties of Soil-Tyre Mixtures. Environmental Technology. 1997;18(8):855860. Available from: https://dx.doi.org/10.1080/09593331808616605.

26) Seda JH, Lee JC, Antonio J, Carraro H. Beneficial use of waste tire rubber for swelling potential mitigation in expansive soils. Soil Improvement. 2007. Available from: https://doi.org/10.1061/40916(235)5.

27) Mukherjee K, Mishra AK. The Impact of Scrapped Tyre Chips on the Mechanical Properties of Liner Materials. Environmental Processes. 2017;4(1):219233. Available from: https://dx.doi.org/10.1007/s40710-017-0210-6.

28) Chan CM. Mechanical properties of clayey sand treated with cement-rubber shreds. Civil Engineering Dimension. 2012;14(1):7-12. Available from: http://dx.doi.org/10.9744/ced.14.1.7-12.

29) Daud N, Yusoff Z, Muhammed A. Ground Improvement of Problematic Soft Soils Using Shredded Waste Tyre. The Sixth Jordanian International Civil Engineering Conference (Jeaconf Org 1-5). 2015.

30) Akbulut S, Arasan S, Kalkan E. Modification of clayey soils using scrap tire rubber and synthetic fibers. Applied Clay Science. 2007;38(1-2):23-32. Available from: https://dx.doi.org/10.1016/j.clay.2007.02.001.

31) Otoko GR, Pedro PP. Cement stabilization of laterite and Chikoko soils using waste rubber fibre. International Journal of Engineering Sciences and Research Technology. 2014;3(10):130-136. Available from: https://www.researchgate.net/publication/267211553. 
32) Kim YT, Kang HS. Engineering Characteristics of Rubber-Added Lightweight Soil as a Flowable Backfill Material. Journal of Materials in Civil Engineering. 2011;23(9):1289-1294. Available from: https://dx.doi.org/10.1061/(asce)mt.1943-5533.0000307.

33) Cabalar AF, Karabash Z, Mustafa WS. Stabilising a clay using tyre buffings and lime. Road Materials and Pavement Design. 2014;15:872-891. Available from: https://dx.doi.org/10.1080/14680629.2014.939697.

34) Tajdini M, Nabizadeh A, Taherkhani H, Zartaj H. Effect of Added Waste Rubber on the Properties and Failure Mode of Kaolinite Clay. International Journal of Civil Engineering. 2017;15(6):949-958. Available from: https://dx.doi.org/10.1007/s40999-016-0057-7.

35) Kim YT, Kang HS. Effects of Rubber and Bottom Ash Inclusion on Geotechnical Characteristics of Composite Geomaterial. Marine Georesources \& Geotechnology. 2013;31(1):71-85. Available from: https://dx.doi.org/10.1080/1064119x.2012.667867.

36) Priyadarshee A, Gupta D, Kumar V, Sharma V. Comparative Study on Performance of Tire Crumbles with Fly Ash and Kaolin Clay. International Journal of Geosynthetics and Ground Engineering. 2015;1(4):1-7. Available from: https://dx.doi.org/10.1007/s40891-015-0033-3.

37) New Delhi: Bureau of Indian Standards. IS:2720 (Part VII). Methods of tests for soil: Determination of water content-dry density relation using light compaction. 1987. Available from: https://law.resource.org/pub/in/bis/S03/is.2720.8.1983.pdf.

38) IS:2720 (Part XVI). Methods of tests for soil: Laboratory determination of CBR. 1973. Available from: https://law.resource.org/pub/in/bis/S03/is.2720.1. 1983.pdf

39) New Delhi: Bureau of Indian Standards. IS:2720 (Part X). Methods of tests for soil: Determination of unconfined compressive strength. New Delhi: Bureau of Indian Standards. 1973. Available from: https:/law.resource.org/pub/in/bis/S03/is.2720.1.1983.pdf.

40) Tang CS, Shi B, Zhao LZ. Interfacial shear strength of fiber reinforced soil Geotextiles and Geomembranes. Geotextiles and Geomembranes. 2010;28:54-62. Available from: http://doi.org/10.1016/j.geotexmem.2009.10.001.

41) Yadav JS, Hussain S, Tiwari SK, Garg A. Assessment of the Load-Deformation Behaviour of Rubber Fibre-Reinforced Cemented Clayey Soil. Transportation Infrastructure Geotechnology. 2019;6(2):105-136. Available from: https://dx.doi.org/10.1007/s40515-019-00073-y.

42) IS:2720 (Part 41). Methods of tests for soil: Measurement of Swelling pressure of soils. New Delhi: Bureau of Indian Standards. 1977. Available from: https://www.jainbookagency.com/newdetails.aspx?id=109436.

43) Viswanadham BVS, Phanikumar BR, Mukherjee RV. Swelling behaviour of a geofiber-reinforced expansive soil. Geotextiles and Geomembranes. 2009;27(1):73-76. Available from: https://dx.doi.org/10.1016/j.geotexmem.2008.06.002.

44) New Delhi: The Indian Road Congress. IRC 37. Guidelines for the design of flexible pavements. 2001. Available from: https://thelibraryofcivilengineer. files.wordpress.com/2015/09/irc-37-2001-guidelines-for-the-design- of-flexible-pavements-2nd-revision.pdf. 